\title{
Perceptions of Pelvic Floor Dysfunction and Rehabilitation Care Among Women in Southeast China After Radical Hysterectomy: a Qualitative Study
}

\section{Yu-ting Lai}

Fujian University of Traditional Chinese Medicine

Ai-wu Lin

The First Affiliated Hospital of Fujian Medical University

Li Ge ( $\nabla 2000005 @ f j t c m . e d u . c n)$

Fujian University of Traditional Chinese Medicine

Zhi-hui Zheng

Fujian University of Traditional Chinese Medicine

\section{Ya-li Wang}

Fujian University of Traditional Chinese Medicine

Hong-hong Yu

Fujian University of Traditional Chinese Medicine

\section{Xin-yong Jiang}

Fujian University of Traditional Chinese Medicine

\section{Research Article}

Keywords: Pelvic floor dysfunction, Radical hysterectomy, Perceptions, Rehabilitation care, Qualitative study

Posted Date: June 3rd, 2021

DOI: https://doi.org/10.21203/rs.3.rs-568188/v1

License: (9) This work is licensed under a Creative Commons Attribution 4.0 International License. Read Full License 


\section{Abstract}

Objective: To investigate the perceptions of pelvic floor dysfunction and rehabilitation care among women after radical hysterectomy and to explore ways to improve quality of care.

Methods: Thirty-six women who underwent radical hysterectomy at a hospital in southeast China were enrolled via purposive sampling. One-on-one semistructured in-depth interviews were conducted. The texts were analyzed via qualitative content analysis (Graneheim \& Lundman).

Results: Four themes were attained: serious lack of knowledge of PFD and rehabilitation care; heavy psychological burden; different coping styles to PFD; and great eagerness to receive multiparty support on PFD rehabilitation care.

Conclusion: The women had a low cognition of pelvic floor dysfunction and rehabilitation care after radical hysterectomy. Poor awareness of pelvic floor dysfunction among women is one of the reasons they do not ask for support from the society and even from family members. Knowledge of pelvic floor dysfunction should be shared and disseminated to the society to raise public awareness of this medical condition. Moreover, knowledge of medical insurance should be popularized, especially in rural areas in southeast of China. Family-centered care is an important way to support women with pelvic floor dysfunction.

\section{Introduction}

Radical hysterectomy is one of the most recommended surgical procedures for gynecological malignancies owing to its high cure rate [1]. However, radical hysterectomy substantially changes the overall structure of the pelvis, thereby increasing the incidence of pelvic floor dysfunction (PFD) [2]. Disruption of local nerve supplies and distortion of anatomical relationships in the pelvic floor after this operation may be main reasons that lead to diseases related to PFD [3].

PFD is a common but not fully understood disease. Its main symptoms are urinary incontinence, constipation, pelvic organ prolapses, and sexual dysfunction [4]. These symptoms impose heavy physical and mental burden to women and greatly influence their daily lives [5] and psychological health [6], such as by negatively impacting their self-care activity and family and work relationships. A study reported that the prevalence of PFDs in low- and middle-income countries is 25\% [7]. A recent meta-analysis of adult Chinese women noted that the prevalence of urinary incontinence is $31.1 \%$, and it has been at a high level since 2005 [8]. Pelvic organ prolapses also affect $9.67 \%$ of urban Chinese women [9]. A study in the USA showed that $66.8 \%$ of participants are not aware of pelvic floor rehabilitation to address PFD [5]. To the best of our knowledge, perceptions of PFD and rehabilitation care among Chinese women after radical hysterectomy have not been explored yet.

For women who develop PFD after undergoing radical hysterectomy, rehabilitation therapy and care are often the primary choice in postoperative rehabilitation; this treatment modality can remarkably improve 
PFD symptoms and prevent its development [10]. Ideally, rehabilitation care for women with this condition should be implemented in the early postoperative period to ensure recovery from this condition [11]. However, women's perceptions of PFD considerably influence their choice and adherence to treatment and care [12]. Therefore, the aim of this study was to investigate the perceptions of PFD and rehabilitation care among women who underwent radical hysterectomy to explore ways to improve quality of care.

\section{Materials And Methods}

This study was conducted at a provincial hospital in southeastern China from March 2019 to July 2019. Women who underwent radical hysterectomy were recruited via purposive sampling according to their education levels, i.e., junior secondary education (9 years), senior secondary education (12-13 years), and higher education (15-19 years) [13]. The inclusion criteria were as follows: underwent radical hysterectomy, including open radical hysterectomy (ORH) and laparoscopic radical hysterectomy (LRH), had no serious complications, mental state was normal, fluent in Mandarin, and signed informed consent. Participants were excluded if they were unable to complete the interview because of insufficient interview time or were emotionally unstable during the interview. This study was approved by the Ethics Committee of the First Affiliated Hospital of Fujian Medical University (FAHFMU [2018] No. 073). All methods in the study were performed in accordance with the Declaration of Helsinki.

Data were collected via semistructured individual interviews. A self-development interview guide consisting of nine questions about perceptions of PFD and rehabilitation care was used for data collection (Table 1). Following the interview guide, a researcher (Y. L.) interviewed each participant faceto-face for 30-45 $\mathrm{min}$ in a separate and quiet room at the hospital. The interviewer noted the nonverbal behavior of the participants. The entire interview was recorded using a digital audio recorder, and then the researcher (Y. L.) transcribed the participants' responses verbatim within $24 \mathrm{~h}$ after each interview. 
Table 1

Interview guide: Questions about perceptions of pelvic floor dysfunction and rehabilitation care among women after radical hysterectomy.

\section{-What do you know about female pelvic floor function?}

- If a woman has pelvic floor dysfunction (such as urinary incontinence), what do you think the cause is?

- How does radical hysterectomy affect you?

-What is your biggest concern after radical hysterectomy?

- How do you think radical hysterectomy will affect pelvic floor function?

-What will you do to treat pelvic floor dysfunction?

-What do you think about the rehabilitation care of pelvic floor function?

- How do you think rehabilitation care of pelvic floor function will affect you?

-What are the factors that affect your rehabilitation care of pelvic floor function?

Data were analyzed using the qualitative content analysis described by Graneheim and Lundman [14]. The analysis included manifest and latent content analysis as follows: (1) the text was read several times to obtain a whole sense of the participants' perception of PFD; (2) the text content was divided into meaning units according to the meaning of expression; (3) the meaning units were compressed and extracted into codes; (4) differences and similarities between codes were compared, and then the sorted codes with commonality were grouped into categories, i.e., manifest content analysis; and (5) the research team fully considered the social and cultural contexts of the interview content, discussed the formed codes and categories, and linked the underlying meanings to form themes, i.e., latent content analysis.

\section{Results}

Thirty-six women who met the inclusion criteria participated in this study. The median age of the participants was 48 years (42-58). Among the participants, 12 had a low educational level, 12 had a middle educational level, and 12 had a high educational level (Table 2). Four themes were formed from the interview texts: serious lack of knowledge of PFD and rehabilitation care; heavy psychological burden; different coping styles to PFD; and great eagerness to receive multiparty support on PFD rehabilitation care. 
Table 2

Participant characteristics $(n=36){ }^{\text {a }}$

\begin{tabular}{|c|c|}
\hline Variable & Value \\
\hline Age, y & $48(42-58)$ \\
\hline \multicolumn{2}{|l|}{ Educational level ${ }^{\mathrm{b}}$} \\
\hline Junior secondary education (9 y) & $12(33.3)$ \\
\hline Senior secondary education (12-13 y) & $12(33.3)$ \\
\hline Higher education (15-19 y) & $12(33.3)$ \\
\hline \multicolumn{2}{|l|}{ Place of residence } \\
\hline Rural area & $20(55.6)$ \\
\hline Urban area & $16(44.4)$ \\
\hline \multicolumn{2}{|l|}{ Occupation } \\
\hline Farmer & $9(25.0)$ \\
\hline Chef & $1(2.8)$ \\
\hline Staff & $4(11.1)$ \\
\hline Teacher & $5(13.9)$ \\
\hline Trader & $8(22.2)$ \\
\hline Lawyer & $2(5.6)$ \\
\hline Freelance & $4(11.1)$ \\
\hline Retirement & $3(8.3)$ \\
\hline \multicolumn{2}{|l|}{ Household income, yuan/month } \\
\hline$<2,000$ & $2(5.6)$ \\
\hline $2,000-5,000$ & $16(44.4)$ \\
\hline $5,000-10,000$ & $10(27.8)$ \\
\hline$>10000$ & $8(22.2)$ \\
\hline \multicolumn{2}{|l|}{ Do you have medical insurance? } \\
\hline Yes & $33(91.7)$ \\
\hline No & $3(8.3)$ \\
\hline
\end{tabular}




\begin{tabular}{|ll|}
\hline Variable & Value \\
\hline Yes & $7(19.4)$ \\
\hline No & $29(80.6)$ \\
\hline Did PFD occur after surgery? & $18(50.0)$ \\
\hline Yes & $18(50.0)$ \\
\hline No & \\
\hline Disease type & $2(5.6)$ \\
\hline Uterine sarcoma & $11(30.5)$ \\
\hline Ovarian cancer & $11(30.5)$ \\
\hline Endometrial cancer & $12(33.4)$ \\
\hline Cervical cancer & \\
\hline Surgical approach & $5(13.9)$ \\
\hline ORH & $31(86.1)$ \\
\hline LRH & $6(4-208)$ \\
\hline Postoperative time, d & \\
\hline $\begin{array}{l}\text { Abbreviation: PFD, pelvic floor dysfunction. ORH, open radical hysterectomy. LRH, laparoscopic } \\
\text { radical hysterectomy. } \\
\text { a Values are given as median (range) or number (percentage). } \\
\text { b Classified according to the education statistic data in 2018 [13]. }\end{array}$ \\
\hline
\end{tabular}

The first theme (serious lack of knowledge of PFD and rehabilitation care) consisted of two categories: limited knowledge of PFD and some knowledge of PFD but limited knowledge of pelvic floor rehabilitation care (Table 3). During the interview, most participants said that they were unaware of PFD. However, after learning the symptoms of PFD, some of the participants suggested that their advanced age and childbirth might have caused their PFD, but they were unsure if PFD was related to their radical hysterectomy. With regard to dealing with PFD, they did not know how to perform rehabilitation care, although some of them recognized the efficacy of this treatment modality. Several women said that they would not seek pelvic floor function rehabilitation care if they did not have symptoms of PFD. Therefore, the participants were unaware of the importance of early rehabilitation care after surgery. One woman stated that "The symptoms were normal, you know...so big surgery...It is not a disease. It needs to be slowly recovered. Do not need to see doctor for it." 
Categories, codes, and meaning units included in the first theme (serious lack of knowledge of PFD and rehabilitation care).

\begin{tabular}{|c|c|c|c|}
\hline Theme & Category & Code & Meaning unit \\
\hline \multirow{6}{*}{$\begin{array}{l}\text { Serious lack } \\
\text { of } \\
\text { knowledge } \\
\text { of PFD and } \\
\text { rehabilitation } \\
\text { care }\end{array}$} & $\begin{array}{l}\text { Limited } \\
\text { knowledge of } \\
\text { PFD }\end{array}$ & $\begin{array}{l}\text { Does not know } \\
\text { what is meant } \\
\text { by PFD }\end{array}$ & $\begin{array}{l}\text { "I don't know what this pelvic floor disorder } \\
\text { means, I don't understand." (Patient 14) }\end{array}$ \\
\hline & & $\begin{array}{l}\text { Believed that } \\
\text { PFD is not a } \\
\text { disease }\end{array}$ & $\begin{array}{l}\text { "The symptoms were normal. You know...so big } \\
\text { surgery... It (the symptoms) is not a disease. It } \\
\text { needs to be slowly recovered. Do not need to see } \\
\text { doctor for it." (Patient 22) }\end{array}$ \\
\hline & & $\begin{array}{l}\text { Unsure if PFD } \\
\text { is related to } \\
\text { radical } \\
\text { hysterectomy }\end{array}$ & $\begin{array}{l}\text { "I think a good doctor and very accurate surgery } \\
\text { will not cause problems in patient's urinary } \\
\text { system at all. I don't know whether previous } \\
\text { surgery will cause this problem to women. I have } \\
\text { never seen it before." (Patient } 6 \text { ) }\end{array}$ \\
\hline & $\begin{array}{l}\text { Have some } \\
\text { knowledge of } \\
\text { PFD but } \\
\text { knowledge of } \\
\text { pelvic floor } \\
\text { rehabilitation } \\
\text { care is limited }\end{array}$ & $\begin{array}{l}\text { Does not } \\
\text { believe the } \\
\text { effect of pelvic } \\
\text { floor function } \\
\text { rehabilitation }\end{array}$ & $\begin{array}{l}\text { "After this operation, my pelvic floor function was } \\
\text { affected. The most obvious symptom is } \\
\text { constipation. ...I think pelvic floor function } \\
\text { rehabilitation seems to be a psychological } \\
\text { comfort. No actual effect. This organ has already } \\
\text { been cut off, so physiological change cannot be } \\
\text { changed." (Patient 15) }\end{array}$ \\
\hline & & $\begin{array}{l}\text { Does not seek } \\
\text { pelvic floor } \\
\text { rehabilitation } \\
\text { care when } \\
\text { without } \\
\text { symptoms }\end{array}$ & $\begin{array}{l}\text { "Vaginal delivery may cause the symptoms of } \\
\text { PFD, like urinary incontinence. However, if I do } \\
\text { not have symptoms of PFD, I will not consider } \\
\text { pelvic floor rehabilitation care unless I have such } \\
\text { symptoms." (Patient 9) }\end{array}$ \\
\hline & & $\begin{array}{l}\text { Not } \\
\text { knowledgeable } \\
\text { of how to do } \\
\text { pelvic floor } \\
\text { rehabilitation } \\
\text { care }\end{array}$ & $\begin{array}{l}\text { "When I stand up, I feel that something in my } \\
\text { abdomen will fall out, which should be related to } \\
\text { the operation. I think the pelvic floor } \\
\text { rehabilitation care may improve the situation, but } \\
\text { I have no idea what I can do for it." (Patient 23) }\end{array}$ \\
\hline
\end{tabular}

The second theme (heavy psychological burden) was further categorized into fear and worry, shame and self-contempt, and guilt and self-blame (Table 4). Some women felt afraid and worried after they developed PFD symptoms; a woman said, "I fear, I fear that the urine cannot be closed...After I walk a little bit, urine can go itself." Some of them were afraid to know pertinent information on the disease; one of them reported, "I do not want to ask (doctors)...Knowing too much will hurt me even more". A few of them were worried about the development of the disease; they said, "Of course, I am anxious. I am worried day and night that pelvic floor dysfunction cannot be cured and develop... I cannot fall sleep all night." In 
general, the participants felt shame and stigma; one woman stated, "It is a terrible thing. I will feel ashamed if I say it (silence). People will say something bad if they know it..." Moreover, they felt selfcontempt because they lost their uterus, which meant that they lost their femininity and they considered that they were no longer a full female. Furthermore, a few of them narrated that their family had spent a lot of money for their treatment. Despite the intervention, they did not fully recover and remained sick because PFD appeared after the operation. Hence, they felt guilty and blamed themselves. Several women showed their apologies to their husband for asexual life; a woman expressed, "I'm sorry for him (husband), I can only let him do whatever he wants."

Table 4

Categories, codes, and meaning units included in the second theme (heavy psychological burden).

\begin{tabular}{|c|c|c|c|}
\hline Theme & Category & Code & Meaning unit \\
\hline \multirow[t]{7}{*}{$\begin{array}{l}\text { Heavy } \\
\text { psychological } \\
\text { burden }\end{array}$} & $\begin{array}{l}\text { Fear and } \\
\text { worry }\end{array}$ & $\begin{array}{l}\text { Fear the } \\
\text { symptoms } \\
\text { of PFD }\end{array}$ & $\begin{array}{l}\text { "I fear, I fear that the urine cannot be closed...After I } \\
\text { walk a little bit, urine can go itself." (Patient 21) }\end{array}$ \\
\hline & & $\begin{array}{l}\text { Fear the } \\
\text { information } \\
\text { about PFD }\end{array}$ & $\begin{array}{l}\text { "I do not want to ask (doctors)...Knowing too much wil } \\
\text { hurt me even more" (Patient 10) }\end{array}$ \\
\hline & & $\begin{array}{l}\text { Worried } \\
\text { about PFD } \\
\text { development }\end{array}$ & $\begin{array}{l}\text { "Of course, I am anxious. I am worried day and night } \\
\text { that pelvic floor dysfunction cannot be cured and } \\
\text { develop... I cannot fall sleep all night" (Patient } 7 \text { ) }\end{array}$ \\
\hline & $\begin{array}{l}\text { Shame } \\
\text { and self- } \\
\text { contempt }\end{array}$ & $\begin{array}{l}\text { Shameful of } \\
\text { PFD }\end{array}$ & $\begin{array}{l}\text { "It (PFD) is a terrible thing. I will feel ashamed if I say it } \\
\text { (silence). People will say something bad if they know } \\
\text { it..." (Patient 31) }\end{array}$ \\
\hline & & $\begin{array}{l}\text { Feelings of } \\
\text { self- } \\
\text { contempt } \\
\text { due to losing } \\
\text { uterus }\end{array}$ & $\begin{array}{l}\text { "The psychological burden is very heavy, and I am self- } \\
\text { contemptuous that I do not be like a whole woman } \\
\text { after the operation (silent), just like what they say." } \\
\text { (Patient 2) }\end{array}$ \\
\hline & $\begin{array}{l}\text { Guilt and } \\
\text { self- } \\
\text { blame }\end{array}$ & $\begin{array}{l}\text { Feelings of } \\
\text { guilt for } \\
\text { being sick } \\
\text { for a long } \\
\text { time }\end{array}$ & $\begin{array}{l}\text { "After cost so much money on the disease, I would feel } \\
\text { guilty if I am always a sick person after I go back } \\
\text { home (silent)... I don't want my family to be worried } \\
\text { about me too much." (Patient 13) }\end{array}$ \\
\hline & & $\begin{array}{l}\text { Self- } \\
\text { condemned } \\
\text { for asexual } \\
\text { life with their } \\
\text { husbands }\end{array}$ & $\begin{array}{l}\text { "Tell you the truth... I did the operation and now I have } \\
\text { the disease (PFD) again...At this point, I'm sorry for } \\
\text { him (husband), I can only let him do whatever he } \\
\text { wants." (Patient 4) }\end{array}$ \\
\hline
\end{tabular}


The third theme presented two coping styles to PDF: one was being positive and the other was being passive (Table 5). Most women with PFD described that they adjusted their mentality, actively sought information on this condition, actively treated the disease, and focused on their recovery. A woman indicated, "First found it out from internet how to deal with it. Then, I went to the hospital for help...I am doing whatever the doctor says." However, a woman chose not to seek treatment and merely accepted her situation as "destiny". Some women only went to see a doctor when their symptoms started to affect their lives. A woman completely stop seeking help because of her advanced age; she said, "My life is definitely getting worse because of the symptoms...I didn't see doctor. Life is getting worse day by day if you are old. It doesn't matter."

\section{Table 5}

Categories, codes, and meaning units included in the third theme (different coping styles to PFD).

\begin{tabular}{|c|c|c|c|}
\hline Theme & Category & Code & Meaning unit \\
\hline \multirow[t]{6}{*}{$\begin{array}{l}\text { Different } \\
\text { coping } \\
\text { styles to } \\
\text { PFD }\end{array}$} & $\begin{array}{l}\text { Positive } \\
\text { coping } \\
\text { mechanism }\end{array}$ & $\begin{array}{l}\text { Actively seek } \\
\text { treatment }\end{array}$ & $\begin{array}{l}\text { "First found it out from internet how to deal with it. Then, } \\
\text { I went to the hospital for help..." (Patient } 6 \text { ) }\end{array}$ \\
\hline & & $\begin{array}{l}\text { Adjust } \\
\text { mentality }\end{array}$ & $\begin{array}{l}\text { "At the same time of treatment, I also adjust my } \\
\text { mentality, should not be pessimistic. Even when facing a } \\
\text { very serious matter, we must be optimistic and accept it." } \\
\text { (Patient 5) }\end{array}$ \\
\hline & & $\begin{array}{l}\text { Follow } \\
\text { doctor's } \\
\text { advice }\end{array}$ & $\begin{array}{l}\text { "I am doing whatever the doctor says. I rest more, } \\
\text { exercise properly, and eat more for nutrition." (Patient 13) }\end{array}$ \\
\hline & $\begin{array}{l}\text { Passive } \\
\text { coping } \\
\text { mechanism }\end{array}$ & $\begin{array}{l}\text { See a doctor } \\
\text { only when } \\
\text { symptoms } \\
\text { affect their } \\
\text { lives }\end{array}$ & $\begin{array}{l}\text { "Well, if it doesn't affect my normal life and work, I } \\
\text { usually don't go to the hospital, unless the symptoms of } \\
\text { PFD are very serious." (Patient 29) }\end{array}$ \\
\hline & & $\begin{array}{l}\text { Give up } \\
\text { seeking help } \\
\text { due to old } \\
\text { age }\end{array}$ & $\begin{array}{l}\text { "My life is definitely getting worse because of the } \\
\text { symptoms...I didn't see doctor. Life is getting worse day } \\
\text { by day if you are old. It doesn't matter." (Patient 1) }\end{array}$ \\
\hline & & $\begin{array}{l}\text { Accept the } \\
\text { situation as } \\
\text { their fate }\end{array}$ & $\begin{array}{l}\text { "I think... Everyone has everyone's fate. It is destined, can't } \\
\text { be changed... it is better to let nature take its course } \\
\text { instead of fighting against the fate... Accept the } \\
\text { arrangements of fate." (Patient 25) }\end{array}$ \\
\hline
\end{tabular}

Abbreviation: PFD, pelvic floor dysfunction.

The fourth theme was great eagerness to obtain multiparty support for PFD rehabilitation care; it included family support, professional support, and social support (Table 6). All women asked for understanding and support from their family, especially from their husband. A woman mentioned, "I do not know 
whether my husband permit me see doctor or not. I will come if my husband let me come." In addition, most of the participants hoped that health care staff could provide professional knowledge, skill support, and care for them. They stated that they would adhere to the health care staff's suggestions. The participants also hoped to receive social support. A woman said that she wanted to receive financial support from the government. They believed that poor awareness of PFD in the society was one of the reasons they did not seek support from the society and even from family members. A woman said, "Although I often read popular medical magazines, I was blank in this field before the doctor told me about the knowledge of pelvic floor dysfunction. I do think it is not known well by people in society. How can we get understanding and support from people around and society?" 
Categories, codes, and meaning units included in the fourth theme (great eagerness to receive multiparty support on PFD rehabilitation care).

\begin{tabular}{|c|c|c|c|}
\hline Theme & Category & Code & Meaning unit \\
\hline \multirow{7}{*}{$\begin{array}{l}\text { Great } \\
\text { eagerness to } \\
\text { receive } \\
\text { multiparty } \\
\text { support on } \\
\text { PFD } \\
\text { rehabilitation } \\
\text { care }\end{array}$} & \multirow[t]{3}{*}{$\begin{array}{l}\text { Hope for } \\
\text { receiving } \\
\text { support from } \\
\text { family } \\
\text { members }\end{array}$} & $\begin{array}{l}\text { Hope for } \\
\text { receiving } \\
\text { understanding } \\
\text { from family } \\
\text { members }\end{array}$ & $\begin{array}{l}\text { "My family refused to pay the cost (silence)...They } \\
\text { do not understand my suffering..." (Patient 18) }\end{array}$ \\
\hline & & $\begin{array}{l}\text { Hoping for } \\
\text { family } \\
\text { members } \\
\text { taking } \\
\text { workload off }\end{array}$ & $\begin{array}{l}\text { "I have a shop...I still don't have energy now... I } \\
\text { have to work in my shop as soon as I am } \\
\text { discharged from hospital. I need my family help } \\
\text { me..." (Patient 13) }\end{array}$ \\
\hline & & $\begin{array}{l}\text { Hope for } \\
\text { receiving } \\
\text { economic } \\
\text { support from } \\
\text { family } \\
\text { members }\end{array}$ & $\begin{array}{l}\text { "I do not know whether my husband permit me } \\
\text { see doctor or not. I will come if my husband let } \\
\text { me come." (Patient 30) }\end{array}$ \\
\hline & \multirow[t]{2}{*}{$\begin{array}{l}\text { Hope for } \\
\text { receiving } \\
\text { support from } \\
\text { professionals }\end{array}$} & $\begin{array}{l}\text { Hope for } \\
\text { receiving } \\
\text { knowledge } \\
\text { and skills } \\
\text { from } \\
\text { professionals }\end{array}$ & $\begin{array}{l}\text { "My friends and I never heard about it (PFD)... } \\
\text { Doctor and nurse teach me how to exercise. I } \\
\text { want to know more from them. I do want that they } \\
\text { can teach me more and guide me more." (Patient } \\
\text { 6) }\end{array}$ \\
\hline & & $\begin{array}{l}\text { Hope for } \\
\text { receiving care } \\
\text { from } \\
\text { professionals }\end{array}$ & $\begin{array}{l}\text { "Leaking urine makes me feel embarrassed. I } \\
\text { don't dare to talk about it to others...Doctors and } \\
\text { nurses are professionals. I especially hope that } \\
\text { they can understand me and care me. I will at } \\
\text { least relieve some of my anxiety." (Patient 16) }\end{array}$ \\
\hline & \multirow[t]{2}{*}{$\begin{array}{l}\text { Hope for } \\
\text { receiving } \\
\text { support from } \\
\text { the society }\end{array}$} & $\begin{array}{l}\text { Hope for } \\
\text { receiving } \\
\text { financial } \\
\text { support from } \\
\text { the } \\
\text { government }\end{array}$ & $\begin{array}{l}\text { "If this (PFD) happens after discharge, oh well, it } \\
\text { will cost a lot of money to see a doctor. How can I } \\
\text { still have money to go to the hospital for pelvic } \\
\text { floor rehabilitation, unless government gives me } \\
\text { financial support." (Patient 4) }\end{array}$ \\
\hline & & $\begin{array}{l}\text { Hope for } \\
\text { popularizing } \\
\text { knowledge of } \\
\text { PFD }\end{array}$ & $\begin{array}{l}\text { "Although I often read popular medical } \\
\text { magazines, I was blank in this field before the } \\
\text { doctor told me about the knowledge of pelvic floor } \\
\text { dysfunction. I do think it is not known well by } \\
\text { people in society. How can we get understanding } \\
\text { and support from people around and society?" } \\
\text { (Patient 26) }\end{array}$ \\
\hline
\end{tabular}

\section{Discussion}


Radical hysterectomy unavoidably damages pelvic floor tissues [2]. Early postoperative rehabilitation can effectively restore pelvic floor functions and reduce the incidence of PFD [15]. Perception is to use selfcognition to explain sensory signals across multiple spatial and temporal scales; thus, perception leads to action [16]. Therefore, perceptions of PFD and rehabilitation care are the key to the recovery of pelvic floor functions for women after radical hysterectomy.

The participants in this study had a serious lack of knowledge of PFD and rehabilitation care. Most of them did not know that radical hysterectomy would result in PFD. The first reason might be that all participants had a malignant tumor. They focused on the treatment and surgical removal of tumor and neglected the impact of the procedure on pelvic floor functions. This observation was consistent with the rule of perception, that is, humans focus on more important tasks in a complex environment [17]. The second reason might be the poor public awareness of PFD that seriously influenced the attitudes and behaviors of the women toward rehabilitation care of PFD. A low social popularization of diseases would lead to misconceptions about the disease among patients and other people in their social circle [18]. A study showed that discussing PFD symptoms among friends is one of the factors that prevent women from actively seeking medical treatment [19]. The third reason might be insufficient health education about PFD in hospitals and the society. Health education from professionals is one of the most economical and effective ways for improving awareness of diseases among patients and the public [20, 21]. However, a systematic review noted a huge gap in knowledge of PFD among most women [22]. Therefore, knowledge of PFD and rehabilitation care should be popularized and strengthened in hospitals and the society via multiple channels, such as brochures, posters, internet, television, and radio.

The occurrence of PFD after radical hysterectomy brings women not only great physical suffering but also huge psychological trauma. In this study, the women feared their diseases and postoperative changes in their body. Given that they lost their uterus after the operation and owing to the specificity of PFD symptoms and location, the women stated that they suffered from negative feelings, such as shame and guilt, which seriously affected their quality of life. The present study indicated that, among the participants, losing their uterus meant losing their femininity, an observation also reported by a previous study [23]. A qualitative study of the psychological consequences of pelvic floor trauma after vaginal birth also reported that the women plunged in negative emotions, such as anxiety, stigma, and failure [24]. Another study showed that feelings of shame about the disease is the main factor why women do not see a doctor [25]. However, the women in the present study affirmed that they were eager to receive professional help. Therefore, health care professionals should focus on the psychological and mental health of affected women, strengthen their confidence that they would recover, and enhance their sense of self-worth sense while conducting health education/pelvic floor function rehabilitation care. In addition, an excellent intervention might be to organize a group of women who suffers from PFD with the assistance of health care professionals. Doing so might alleviate their suffering, and they could receive understanding and support from each other.

The interviews revealed that most of the participants adopted a positive coping mechanism in the face of PFD after radical hysterectomy. However, some of them adopted a negative coping mechanism, such as 
seeing a doctor only when the symptoms had affected their lives, gave up seeking help, and accepted their condition as their fate. Several reasons may explain these observations. First, some of them believed that PFD is an inevitable suffering brought by aging, and disease management is unnecessary in their old age. This belief was similar to that described by Vethanayagam et al. [26]. Second, the public's misconceptions on PFD stigmatized the women with this disease because of poor social awareness. The stigma reduces the possibility of women disclosing their illness and seeking help [27]. Third, owing to the overarching influence of traditional Chinese concepts, some women in rural areas have a low degree of self-identity and largely rely on their husbands when it comes to making decisions about major family affairs [28]. As wives and mothers, women in traditional Chinese culture assume the responsibility as caregivers in the family, prioritizing family obligations over their own health and hiding their own needs to decrease the burden and not impose on the family [29]. These reasons not only highlighted the importance of popularizing PFD knowledge in the society but also emphasized the importance of improving women's self-identity.

An effective support system for individuals can reduce psychological burden, improve the level of disease response, and ultimately promote disease recovery [30]. With regard to family support, the participants hoped to receive understanding and support from their families, especially from their husbands. A study reported that cooperation between husbands and wives is necessary in the prevention and treatment of chronic diseases, such as PFD [31]. The closer the family relationship is, the stronger the couple's coping ability will be, and the better they can deal with the problems caused by the disease [32]. Given that PFD is related to privacy and sex, understanding and support from husbands are especially important. Therefore, family-centered care is an important way to support women with PFD. Health care professionals should focus on husbands, help women receive understanding and support from family members, and encourage family members to actively participate in women's rehabilitation care.

Moreover, the participants hoped to receive social support. Social support can not only promote patients' healthy behaviors but also promote their compliance with medical regimens [33, 34]. A low income usually negatively affects people's awareness of diseases and willingness to seek medical treatment [35]. Owing to the increasing number of patients with PFD, basic medical insurance for pelvic floor function rehabilitation care is also necessary to reduce the financial burden on women and increase their willingness to seek medical help. The medical insurance system in China covers all Chinese citizens living in the country. Thus, people can enjoy preferential medical treatment at a relatively low price [36]. However, some women from rural areas revealed during the interviews that they did not have medical insurance, suggesting that the public, especially in rural areas, not only lacks knowledge of PFD but also of medical insurance.

This study has several limitations. First, the data may not be sufficient. The results might have been affected by some nuances in the translation of the texts from Chinese to English. Nevertheless, a qualitative study through detailed interviews and observations can provide insights into individuals' thoughts, behavior, and understanding in life [37]. This study offered evidence on the low cognition of PFD and rehabilitation care after radical hysterectomy among women and the society. This study 
explored the underlying reasons and specified various ways to improve the quality of care for women with PFD.

In conclusion, this study explored the low cognition of pelvic floor dysfunction and rehabilitation care among women living in southeast China after radical hysterectomy. The poor awareness of PFD in the society is one of the reasons women did not seek support from the society and even from family members. Therefore, knowledge of PFD must be popularized to raise public awareness of this condition. In rural areas in southeast of China, knowledge of medical insurance must also be popularized. Familycentered care is an important way to support women with PFD.

\section{Declarations}

\section{Ethics approval and consent to participate}

The study was approved by the Ethics Committee of the First Affiliated Hospital of Fujian Medical University (Ethics Approval Number: FAHFMU [2018] No. 073). All participants have signed informed consent. We also confirm that all methods were carried out in accordance with the regulations of Declaration of Helsinki.

\section{Consent for publication}

Not Applicable.

\section{Availability of data and materials}

The datasets used and/or analyzed during the current study are available from the corresponding author on reasonable request.

\section{Competing interests}

All authors declare that they have no competing interests.

\section{Funding}

No funding received.

\section{Authors' contributions}


Y. L. participated in the design of the study, data collection, data analysis and writing the main manuscript text. A. L. participated in the design of the study, data collection, data analysis and preparing the manuscript. L. G. participated in the design of the study, data analysis, preparing the manuscript, interpretation, and critical revision of the manuscript for important intellectual content. Z. Z. participated in data analysis, interpretation, and critical revision of the manuscript for important intellectual content. Y. W. participated in data analysis, interpretation, and critical revision of the manuscript for important intellectual content. H. Y. participated in data analysis, preparing the manuscript. X. J. participated in data analysis, preparing the manuscript. All authors read and approved the final manuscript.

\section{Acknowledgements}

We are grateful to everyone in the First Affiliated Hospital of Fujian Medical University who helped with recruitment and all participants who shared their valuable experiences in this study.

\section{References}

1. Ebina $Y$, Mikami M, Nagase S, Tabata T, Kaneuchi M, Tashiro H, et al. Japan Society of Gynecologic Oncology guidelines 2017 for the treatment of uterine cervical cancer. Int J Clin Oncol 2018; 24:1-19. https://doi.org/10.1007/s10147-018-1351-y

2. Laterza RM, Sievert KD, de Ridder D, Vierhout ME, Haab F, Cardozo L, et al. Bladder function after radical hysterectomy for cervical cancer. Neurourol Urodyn 2015; 34:309-15. https://doi.org/10.1002/nau.22570

3. Laterza RM, Salvatore S, Ghezzi F, Serati M, Umek W, Koelbl H. Urinary and anal dysfunction after laparoscopic versus laparotomic radical hysterectomy. Eur J Obstet Gyn R B 2015; 194:11-6. https://doi.org/10.1016/j.ejogrb.2015.08.005

4. Wang Y, Hart DL, Mioduski JE. Characteristics of patients seeking outpatient rehabilitation for pelvicfloor dysfunction. Phys Ther 2012; 92:1160. https://doi.org/10.2522/ptj.20110264

5. Burkhart R, Couchman K, Crowell K, Jeffries S, Monvillers S, Vilensky J. Pelvic floor dysfunction after childbirth: occupational impact and awareness of available treatment. OTJR (Thorofare $\mathrm{NJ}$ ) 2020:201901695. https://doi.org/10.1177/1539449220970881

6. Ghetti C, Skoczylas LC, Oliphant SS, Nikolajski C, Lowder JL. The emotional burden of pelvic organ prolapse in women seeking treatment: a qualitative study. Female Pelvic Med Reconstr Surg 2015; 21:332-8. https://doi.org/10.1097/SPV.0000000000000190

7. Islam RM, Oldroyd J, Rana J, Romero L, Karim MN. Prevalence of symptomatic pelvic floor disorders in community-dwelling women in low and middle-income countries: a systematic review and metaanalysis. Int Urogynecol J 2019; 30:2001-11. https://doi.org/10.1007/s00192-019-03992-z

8. Kun Y, Zhenguo X, Zhihai Y, Sheng L, Meiping L. Prevalence of urinary incontinence in Chinese adult women: a meta-analysis. Chinese Journal of Evidence-Based Medicine 2019; 19:36-43. https://doi.org/10.7507/1672-2531.201806057 
9. Zhiyi L, Lan Z, Tao X, Qing L, Zhaoai L, Jian G, et al. An epidemiologic study of pelvic organ prolapse in urban Chinese women: a population $₫$ based sample in China. National Medical Journal of China 2019; 11:857-61. https://doi.org/10.3760/cma.j.issn.0376-2491.2019.11.012

10. Arnouk A, De E, Rehfuss A, Cappadocia C, Dickson S, Lian F. Physical, complementary, and alternative medicine in the treatment of pelvic floor disorders. Curr Urol Rep 2017; 18:47. https://doi.org/10.1007/s11934-017-0694-7

11. Wenlin L. Application of Rehabilitation Training in Pelvic Floor Dysfunction after Total Hysterectomy. Modern Medicine and Health Research Electronic Journal 2017; 1:133-4.

12. Tinetti A, Weir N, Tangyotkajohn U, Jacques A, Thompson J, Briffa K. Help-seeking behaviour for pelvic floor dysfunction in women over 55: drivers and barriers. Int Urogynecol J 2018; 29:1645-53. https://doi.org/10.1007/s00192-018-3618-2

13. Ministry of Education of the People 's Republic of China. Education Statistic Data in 2018.http://www.moe.gov.cn/s78/A03/moe_560/jytjsj_2018/qg/201908/t20190812_394239.html. Published 2019. Accessed August 8, 2019.

14. Graneheim UH, Lundman B. Qualitative content analysis in nursing research: concepts, procedures and measures to achieve trustworthiness. Nurs Educ Today 2004; 24:105-112. https://doi.org/10.1016/j.nedt.2003.10.001

15. Wenjun L, Limin F. Study on correlation of time and pelvic floor dysfunction after hysterectomy. National Medical Frontiers of China 2012; 7:7-8,36. https://doi.org/10.3969/j.issn.16735552.2012.13.0004

16. Clark A. Whatever next? Predictive brains, situated agents, and the future of cognitive science. Behav Brain Sci 2013; 36:181-204. https://doi.org/10.1017/S0140525X12000477

17. Boag RJ, Strickland L, Loft S, Heathcote A. Strategic attention and decision control support prospective memory in a complex dual-task environment. Perceptions 2019; 191:103974. https://doi.org/10.1016/j.cognition.2019.05.011

18. Cox JH, Nahar A, Termine C, Agosti M, Balottin U, Seri S, et al. Social stigma and self-perception in adolescents with tourette syndrome. Adolescent Health, Medicine and Therapeutics 2019; 10:75-82. https://doi.org/10.2147/AHMT.S175765

19. Buurman MB, Lagro-Janssen AL. Women's perception of postpartum Pelvic floor dysfunction and their help-seeking behaviour: a qualitative interview study. Scand J Caring Sci 2013;27: 406-413. https://doi.org/10.1111/j.1471-6712.2012.01044.x

20. Liu XL, Shi Y, Willis K, Wu CJ, Johnson M. Health education for patients with acute coronary syndrome and type 2 diabetes mellitus: an umbrella review of systematic reviews and metaanalyses. BMJ Open 2017; 7: e16857. https://doi.org/10.1136/bmjopen-2017-016857

21. Cheewakriangkrai C, Kietpeerakool C, Charoenkwan K, Pattanittum P, John D, Aue-Aungkul A, et al. Health education interventions to promote early presentation and referral for women with symptoms of endometrial cancer. Cochrane Database Syst Rev 2020; 3: D13253.

https://doi.org/10.1002/14651858.CD013253.pub2 
22. Fante JF, Silva TD, Mateus-Vasconcelos E, Ferreira C, Brito L. Do women have adequate knowledge about pelvic floor dysfunctions? A systematic review. Rev Bras Ginecol Obstet 2019; 41:508-19. https://doi.org/10.1055/s-0039-1695002

23. Silva Cde M, Vargens OM. Woman experiencing gynecologic surgery: coping with the changes imposed by surgery. Rev Lat Am Enfermagem 2016; 24: e2780. https://doi.org/10.1590/15188345.1081.2780

24. Skinner EM, Barnett B, Dietz HP. Psychological consequences of pelvic floor trauma following vaginal birth: a qualitative study from two Australian tertiary maternity units. Arch Womens Ment Health 2018; 21:341-51. https://doi.org/10.1007/s00737-017-0802-1

25. Nguyen A, Cheung A, Berg W, Lee W, Weissbart S, Kim J. What's in a name? Choosing a title for a female pelvic medicine and reconstructive surgery clinic: A prospective questionnaire. Neurourol Urodyn 2020; 39:197-202. https://doi.org/10.1002/nau.24168

26. Vethanayagam N, Orrell A, Dahlberg L, McKee KJ, Orme S, Parker SG, et al. Understanding helpseeking in older people with urinary incontinence: an interview study. Health Soc Care Comm 2017; 25:1061-9. https://doi.org/10.1111/hsc.12406

27. Alshammari S, Alyahya MA, Allhidan RS, Assiry GA, AlMuzini HR, AlSalman MA. Effect of urinary incontinence on the quality of life of older adults in riyadh: medical and sociocultural perspectives. Cureus 2020; 12: e11599. https://doi.org/10.7759/cureus.11599

28. Zhongwu L, Qunyong W. Psychological Channel to Improve Women's Family Status: A Case of Selfesteem. Statistical Research 2020; 11: 44-56. https://doi.org/10. 19343 /j.cnki.111302/c.2020.11.004

29. Chang L, Basnyat I. Exploring Family Support for Older Chinese Singaporean Women in a Confucian Society. Health Commun 2017; 32(5):603-11. https://doi.org/10.1080/10410236.2016.1146568

30. Jeong A, An JY. The moderating role of social support on depression and anxiety for gastric cancer patients and their family caregivers. Plos One 2017; 12: e0189808. https://doi.org/10.1371/journal.pone.0189808

31. Martire LM, Helgeson VS. Close relationships and the management of chronic illness: Associations and interventions. Am Psycho/ 2017; 72: 601-612. https://doi.org/10.1037/amp0000066

32. Checton MG, Magsamen-Conrad K, Venetis MK, Greene K. A dyadic approach: applying a developmental-conceptual model to couples coping with chronic illness. Health Educ Behav 2015; 42: 257-267. https://doi.org/10.1177/1090198114557121

33. Barton C, Effing TW, Cafarella P. Social support and social networks in COPD: a scoping review. COPD 2015; 12:690-702. https://doi.org/10.3109/15412555.2015.1008691

34. Usta YY. Importance of social support in cancer patients. Asian Pac J Cancer Prev 2012; 13:3569-72. https://doi.org/10.7314/apjcp.2012.13.8.3569

35. Beibei D, Jianhong Q, Guangchao G. Survey of cognitive level of puerpera on pelvic floor dysfunction. Chinese Nursing Research 2018; 32:3113-3116. https://doi.org/10.3969/j.issn.1009 6493.2018.19.032 
36. Yingfeng $F$, Chenyu Z. The long-term effects of health on poverty reduction--the evaluation based on the new cooperative medical scheme. Modern Economic Science 2020; 4:17-28. http://jjkx.xjtu.edu.cn//\#/digest?ArticlelD=963

37. Denny E, Weckesser A. Qualitative research: what it is and what it is not: Study design: qualitative research. BJOG 2019; 126:369. https://doi.org/10.1111/1471-0528.1519 